
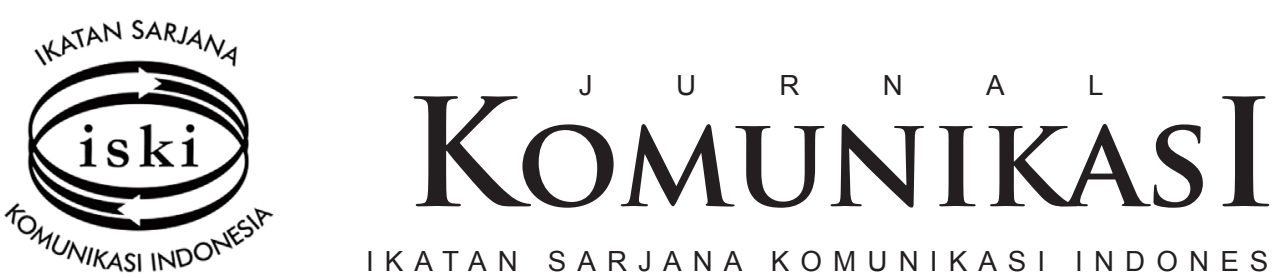

IKATAN SARJANA KOMUNIKASI INDONESIA

\title{
PERSPEKTIF TRIPLEHELIX DALAM NATION BRAND INDONESIA
}

\author{
Irwansyah \\ Departemen Ilmu Komunikasi Universitas Indonesia \\ irwansyah09@ui.ac.id
}

\begin{abstract}
Abstrak
Momentum memperkuat nation brand Indonesia semakin tinggi seiring dengan penguatan sistem pemerintahan yang demokratis dan eksplorasi keberagaman kultur. Namun persepsi negatif masih muncul dan Indonesia belum memiliki reputasi yang baik di mata masyarakat dari negara lain. Oleh karena itu dengan pendekatan grounded theory berbasis wawancara mendalam, konsep triple helix yang memadukan aspek pemerintah, bisnis, dan masyarakat sipil digali dan dianalisis secara tematik. Hasil temuan memperlihatkan, perspektif triple helix dalam nation brand dapat dipertimbangkan sebagai kekuatan yang penting dan tidak terpisahkan. Mulai dari kualitas sistem pelayanan terpadu, reformasi birokrasi, revolusi mental, sinkronisasi antar sektor dan regulasi, kualitas sumber daya manusia, budaya mental bekerja, infrastruktur, fasilitas, nilai luhur dan filosofis bangsa, kemasan dan daya tahan produk merupakan penguat dan pelengkap keramahtamahan Indonesia dalam membangun nation brand.
\end{abstract}

Kata Kunci: Triplehelix, Nation Brand, Reformasi Birokrasi, Revolusi Mental

\section{PENDAHULUAN}

Indonesia merupakan negara kepulauan dengan sistem pemerintahan demokratis (Suleman \& Junaedhie, 2010). Kemudian, dari keadaan geografis, iklim tropis Indonesia menjadikan negara ini subur dan makmur. Selain itu, Indonesia juga dikenal sebagai negara yang kaya dengan hasil bumi dan tambangnya. Dari sisi masyarakatnya, rakyat Indonesia terdiri dari berbagai suku bangsa yang menggunakan beragam bahasa. Keberagaman etnis tidak menjadikan Indonesia terpecah belah, melainkan menjadikan negara ini sebagai sebuah kesatuan yang unik dan kaya akan keberagaman kultur (Oentoro, 2010). Selain kekayaan kultur, Indonesia juga memiliki banyak tempat indah yang dapat dijadikan tempat untuk berwisata dan berlibur serta masyarakat yang sangat ramah kepada para pendatang. Hal ini merupakan satu dari banyak alasan orang-orang dari negara lain gemar datang ke Indonesia (Warta Ekonomi, 1998).

Di tahun 2016 ini Indonesia berusia 71 tahun.
Namun, banyak persepsi negatif (Antara, 2011) dan hingga saat ini belum ada gagasan untuk membangun brand atau merek bangsa Indonesia secara komprehensif. Momentum ini seharusnya dapat menjadi langkah awal Indonesia dalam meningkatkan nation branding-nya. Nation branding sebagai presentasi diri yang stratejik dari suatu negara dengan tujuan untuk menciptakan modal reputasional melalui promosi terhadap ketertarikan ekonomi, politik dan sosial, baik di dalam negeri maupun di luar negeri. Padahal, pada tahun 2011, Indonesia sudah mendengungkan wacana nation branding melalui majalah Warta Ekspor yang dikeluarkan oleh Kementrian Perdagangan Republik Indonesia. Namun, wacana ini masih berfokus hanya pada citra dari Indonesia. Padahal, konsep nation branding tidaklah sama dengan konsep citra, walaupun memang kedua konsep ini saling terkait. Konsep nation branding ini meliputi seluruh dimensi yang perlu dibenahi dengan terintegrasi, termasuk didalamnya dimensi ekonomi, pariwisata, 
kebudayaan, pemerintahan, dan lain-lain.

Oleh karena itu dirasakan perlu untuk meningkatkan nation branding Indonesia ini berangkat dari beberapa data hasil pengukuran nation brand index oleh banyak konsultan di dunia. Berdasarkan pengukuran secara global di tahun 2010 yang lalu, menurut Anhold GfK Roper Nation Brand Index yang melihat reputasi negara oleh negara lain, Indonesia berada di ranking 44 dengan skor 49,05 (di tahun 2009 menempati ranking 41) dari 50 negara. Sedangkan di tahun 2011, menurut Bloom Consulting Country Branding Ranking, Indonesia menempati ranking 36 dalam attraction to trade, dan ranking 32 dalam attraction to tourism dari 193 negara di dunia. Dari laporan Brand Finance Nation Brand tahun 2011, Indonesia menduduki posisi 32 yang sebelumnya menempati posisi 33 di tahun 2010 dari 100 negara.

Sedangkan menurut Future Brand Country Brand Index, di tahun 2012-2013, Indonesia menempati ranking 78 (di tahun 2011 menempati ranking 76 dan di tahun 2010 menempati ranking 72) dari 118 negara. Secara keseluruhan, keempat pengukuran yang dilakukan oleh institusi asing terhadap Indonesia tersebut memperlihatkan bahwa indeks negara Indonesia belum dapat menempati posisi 20 besar, apalagi 10 besar. Hal ini menunjukkan bahwa Indonesia belum memiliki reputasi yang baik dimata masyarakat dari negara lain.

Fakta ini tentu saja mengkhawatirkan karena reputasi yang baik dari sebuah negara merupakan sebuah hal yang harus dimiliki, terutama di era pasar global saat ini. Hal ini dikarenakan saat ini, proses jual beli tidak hanya dilakukan di antara satu daerah dengan daerah lainnya dalam sebuah negara. Tetapi, proses jual beli dilakukan antara satu negara dengan negara lainnya. Dengan memiliki reputasi yang baik, Indonesia akan dapat memperoleh kepercayaan dari negara-negara lain untuk bekerjasama dengan mereka dan tidak lagi dipandang sebelah mata dalam partisipasinya di kompetisi global (Hasan, 2007). Oleh karena itu artikel ini mendikusikan nation branding Indonesia dari berbagai perspektif.

\section{KERANGKA TEORITIS}

Dalam rangka memberikan brand untuk dirinya, suatu negara membutuhkan kebijakan komunikasi yang terintegrasi atau kerangka kerja yang mengkoordinasikan cara-cara negara-negara memerankan atau menggambarkan diri mereka
(Brymer, 2003). Gambaran tersebut harus lah konsisten dan dapat diingat, agar dapat dibedakan dengan negara lainnya. Nation brand yang kuat tidak hanya bagus untuk segi parwisata dan bisnis, namun juga membuat sebuah ekosistem branding atau 'ecosystem of branding' yang utuh bagi sebuah negara (Lindstrom, 2006, dalam Outhavong, 2007, hal.16).

Suatu nation brand harus lah merefleksikan keutuhan dalam suatu definisi yang terdiri dari imej atau citra dari kumpulan manusia, budaya, tanah, pemerintahan dan karakteristik utama dari sebuah negara (Outhavong, 2007). Nation, dapat didefinisikan sebagai suatu kelompok manusia yang saling berhubungan atau terkait satu sama lain melalui aspek-aspek yang umum, yaitu budaya, etnisitas dan ideologi.

Konsep nation branding bukanlah sebuah konsep baru, namun juga bukan konsep yang sudah hadir sejak lama. Tercatat beberapa penelitian mengenai nation branding pernah dilakukan oleh sejumlah peneliti. Pada tahun 2006, Bostwana melakukan penelitian mengenai nation branding negaranya. Kemudian, di tahun 2011, Francis Odey Ntamu pernah meneliti mengenai nation branding Nigeria. Beberapa konsultan riset seperti Anholt-GfK Roper, East West Communication, dan lain-lain pun setiap tahunnya mengeluarkan Nation Brand Index negaranegara di dunia.

Konsep ini pertama kali dicetuskan oleh Simon Anholt pada tahun 1996 untuk membantu negaranegara di dunia membentuk strategi, kebijakan, inovasi, dan investasinya. Penelitian-penelitian yang dilakukan mengenai nation branding ini menghasilkan banyak kesimpulan yang pada akhirnya memperkaya pengetahuan kita mengenai nation branding. Dari penelitian-penelitian ini juga muncul berbagai macam definisi mengenai nation branding. Menurut Soucewatch (2007), nation branding adalah cara sebuah negara dipersepsikan oleh khalayaknya. Tim peneliti International Marketing Review (2010) mencoba melihat kaitan antara kegiatan nation branding dengan konsep integrated marketing communication. Konsep nation branding ini memang bukan konsep yang telah ada sejak dulu, namun, konsep ini adalah suatu hal yang penting dimiliki oleh setiap negara di masa pasar global saat ini. Itulah yang menyebabkan banyak penelitian mengenai nation branding yang muncul belakangan ini dan penelitian-penelitian tersebut tentu saja memperkaya bahan studi literatur dalam konsep ini. 
Dimensi yang paling populer dalam nation branding adalah dimensi versi Simon Anholt yang juga digunakan oleh Anholt-GfK Roper untuk melihat nation brand index berbagai negara. Terdapat setidaknya enam dimensi nation branding antara lain ekspor, pemerintahan, budaya dan peninggalan sejarah, masyarakat, investasi dan imigrasi serta pariwisata. Sedangkan dalam artikel ini, triplehelix nation branding merupakan dimensi yang memberikan berbagai perspektif mengenai Indonesia. Triplehelix nation branding terdiri dari pemerintah, bisnis dan masyarakat sipil. Government (pemerintah) yang dimaksud adalah kementrian atau lembaga nonkementrian yang bersinggungan dengan nation branding Indonesia. Selain itu kedutaan Negara asing di Indonesia yang mewakili Asia-Pacific Economic Conference (APEC), Timur Tengah, Uni Eropa dan Afrika. Business diharapkan akan mendapatkan narasumber yang berasal dari perwakilan kamar dagang Negara asing di Indonesia. Sedangkan Civil Society diharapkan berasal lembaga swadaya masyarakat (LSM) asing yang berada di Indonesia, dan atau perwakilan lembaga-lembaga $\mathrm{UN}$ yang berkantor di Indonesia.

\section{METODE PENELITIAN}

Studi ini menggunakan pendekatan kualitatif untuk mengeksplorasi berbagai perspektif terkait nation branding Indonesia. Perspektif branding Indonesia diperoleh dari triplehelix nation branding yang terdiri dari pemerintah, bisnis dan masyarakat sipil. Pemerintah terdiri dari Kementerian Pariwisata dan Badan Koordinasi Penanaman Modal (BKPM) Republik Indonesia. Kedua lembaga ini dipilih karena telah menginisiasi program branding Indonesia. Kementerian Pariwisata memiliki slogan Wonderful Indonesia yang bertujuan menarik turis asing berkunjung ke Indonesia. Sedangkan BKPM telah menggagas slogan Remarkable Indonesia dengan tujuan menarik investor asing untuk menanamkan modal di Indonesia. Kemudian kalangan bisnis terdiri dari investor asing yang menjalankan bisnis di Indonesia, yaitu Jepang. Kemudian dari masyarakat sipil, terdapat lembaga swadaya masyarakat yang bergerak dalam pendidikan, institusi budaya dan bahasa dari Jerman, dan seorang ekspatriat dari Inggris.

Wawancara mendalam dilakukan untuk menggali nation branding Indonesia berdasarkan perspektif masing-masing pihak. Hasil wawancara dibuat transkrip verbatim untuk memudahkan kategorisasi. Sedangkan teknik analisis data verbatim menggunakan grounded theory. Pendekatan ini seringkali digunakan dalam penelitian kualitatif. Grounded theory bukanlah teori tetapi suatu pendekatan yang melihat keseluruhan teori dari data yang dihasilkan. Kemudian, melalui pendekatan ini, dapat menghasilkan konsep-konsep baru daripada teori (Bryman, 2008). Teknik grounded theory yang biasa digunakan adalah koding. Dalam penelitian kualitatif, koding merupakan proses utama dalam mengelola data. Tidak seperti koding kuantitatif yang konstan, koding kualitatif berpotensi untuk adanya revisi dan bersifat cair (Bryman, 2008). Strauss dan Corbin (1990) membagi koding menjadi tiga tipe, yaitu open coding, axial coding, dan selective coding.

\section{HASIL PENELITIAN}

Pada bagian temuan data dan pembahasan, terbagi dalam tiga sub berdasarkan triple helix nation branding yaitu (1) pemerintah, (2) bisnis dan (3) masyarakat sipil sebagai berikut.

\section{Pemerintah}

Dalam pembentukan nation branding, Indonesia sedang berada dalam proses repositioning. Seperti halnya yang diungkapkan oleh Badan Koordinasi Penanaman Modal (BKPM).

"Sepuluh tahun yang lalu, banyak negara yang meragukan Indonesia karena kekhawatiran akan balkanisasi usai reformasi, kurangnya keamanan seperti pemboman di Bali dan hotel di Jakarta, bencana alam tsunami di Aceh, dan perekonomian yang belum sepenuhnya membaik. Sekarang, tentunya kita tidak ingin terus dipersepsikan seperti itu oleh negara lain. Maka, proses repositioning dimulai." (Wawancara informan)

Proses ini bisa dilihat dari gencarnya berbagai kementerian terkait, khususnya yang berhubungan dengan pariwisata, perdagangan, dan investasi dalam menyampaikan berbagai pesan mengenai kondisi Indonesia terbaru. Kementerian tersebut melakukan promosi di berbagai media dalam dan luar negeri.

Salah satu promosi yang telah dilakukan adalah menciptakan tagline promosi. Seperti Kementerian Pariwisata dan Ekonomi Kreatif yang mengusung 'Wonderful Indonesia', Kementerian Perdagangan dengan '100 persen Indonesia', dan BKPM dengan 'Remarkable Indonesia'. Berbagai tagline yang berbeda-beda ini memperlihatkan belum sepenuhnya 
sadar akan pentingnya pembentukan citra dan nation branding karena terkesan belum terkoordinasi dengan baik. Walaupun, tagline hanya bagian dari brand, namun perbedaan ini menunjukkan kekurangseragaman pesan yang ingin disampaikan ke dunia internasional mengenai Indonesia.

Kemudian, dalam masa-masa repositioning ini, pemerintah mulai berkoordinasi kembali dengan lebih baik untuk membangun brand Indonesia. Salah satunya, dengan melakukan kegiatan promosi bersama antara BKPM, Kementerian Perdagangan, serta Kementerian Pariwisata dan Ekonomi Kreatif melalui Trade Tourism Investment (TTI). Melalui kegiatan ini, Pemerintah mencoba membentuk presepsi masyarakat asing bahwa Indonesia adalah negara yang kondusif dengan potensi yang luar biasa untuk melakukan wisata, perdagangan, maupun investasi.

Koordinasi sejenis ini dilakukan kembali ketika BKPM mengadakan Gelar Potensi Investasi Daerah (GPID) dan Seminar Nasional Indonesia (SNI) yang pelaksanaannya digabungkan dengan kegiatan Kementerian Perdagangan, Trade Expo Indonesia (TEI) bertema "Trade to Invest in Remarkable Indonesia". Melalui kegiatan ini, BKPM dan Kementerian Perdagangan berusaha untuk menyampaikan pesan kepada para pelaku usaha bahwa Indonesia adalah tempat yang 'remarkable' untuk berbisnis baik perdagangan maupun investasi.

Faktor keamanan birokrasi juga mempengaruhi investasi, yaitu birokrasi yang berbelit-belit. Menurut perwakilan dari salah satu pemerintah asing, mereka bisa mengelilingi 41 meja di bea cukai untuk mengantongi surat izin. Hal ini kurang efisien, dan profesional. Akhirnya, saat ini dari BKPM melakukan reformasi birokrasi dengan menerapkan sistem Pelayanan Terpadu Satu Pintu (PTSP). Sistem ini diterapkan untuk semua birokrasi dari level nasional hingga daerah.

"Di PTSP punya wewenang untuk memproses perizinan. Sehingga, mereka tinggal datang dan langsung diproses izinnya. Kita bikin mereka senyaman dan semudah mungkin, dengan datang sendiri pun tanpa perlu hire konsultan, law firm, atau calo. Kita kasih karpet merah untuk mereka. Kita juga baru keluarkan, investment tracking, mempermudah mereka melihat jalannya proses perizinan, kayak pos, kita kan bisa lihat barangnya sudah sampai mana." (Wawancara informan)
Reformasi inilah yang diinginkan oleh para investor dari negara manapun agar mereka merasa nyaman, aman, dan diuntungkan menanamkan modalnya di Indonesia. Reformasi ini pun dirasakan oleh agen kerjasama Jepang yang menyatakan bahwa pelayanan yang ditawarkan pemerintah Indonesia sudah lebih efisien, dan jarang ada pungutan liar.

Investasi yang masuk ke Indonesia seringkali terhambat dengan permasalahan infrastruktur. Indonesia dianggap memiliki potensi yang besar untuk mengembangkan industri. Namun infrastruktur seperti jalan raya dan pelabuhan yang tidak memadai akan menghambat investasi tersebut. Hal ini juga terjadi pada sektor pariwisata. Infrastruktur jalan akses ke tempat wisata belum tertata dengan baik.

Dalam mempromosikan pariwisata Indonesia, Kementerian Pariwisata menyatakan terdapat tujuh minat khusus yang diusung yaitu wisata budaya dan sejarah, alam dan eko wisata, olahraga dan rekreasi, kapal pesiar, kuliner dan belanja, kesehatan dan kebugaran, serta wisata konvensi, insentif, pameran dan event.

Wisata budaya meliputi berbagai tempat kerajinan lokal, pasar-pasar tradisional, desa wisata, dan lainnya yang berhubungan dengan tempat wisatawan bisa melihat berbagai aktivitas tradisional masyarakat lokal yang mencerminkan budaya setempat. Wisata sejarah meliputi berbagai tempat bersejarah di Indonesia, seperti candi, benteng, tempat ibadah kuno, dan juga museum.

Contoh wisata budaya dan sejarah yaitu Pulau Penyengat di Kepulauan Riau, upacara Kasada di Gunung Bromo, berkeliling kota tua di Jakarta, dll. Wisata alam dan eko wisata meliputi tempat wisata yang menawarkan kekayaan alam dengan segala jenis flora dan faunanya, misalnya, mengamati lumba-lumba liar di Pantai Lovina Bali, bermain pasir putih di Pantai Beras Basah Kalimantan Timur, atau mengunjungi Taman Nasional Gunung Leuser di Sumatera. Sementara wisata olahraga dan rekreasi adalah tempat untuk berolahraga sekaligus berwisata karena diperkenalkan dengan keindahan alamnya, misal, berbagai spot diving Manado dan Lombok, lokasi surfing di Kuta Bali dan Mentawai Sumatera Barat. Seringkali kegiatan olahraga ini juga dikemas dalam bentuk kompetisi antarnegara, seperti Tour de Singkarak di Sumatera Barat, dan International Celebes Dragon Boat Festival.

Wisata kapal pesiar yaitu tempat bagi kapal pesiar untuk berlabuh dan menikmati keindahan 
kepulauan Indonesia. Maka, pemerintah harus mengembangkan infrastruktur seperti pelabuhan yang memadai bagi kapal pesiar. Selain itu, juga diadakan event bahari berskala internasional, seperti Sail Morotai. Wisata kuliner dan belanja adalah tempat yang menjajakan berbagai makanan khas, pernak-pernik, pakaian, dll. Misalnya, mencicipi sup jagung di Gorontalo, berbelanja noken di Papua, atau berbelanja aneka produk fashion dengan harga miring di Festival Jakarta Great Sale.

Wisata kesehatan dan kebugaran yaitu meliputi tempat-tempat bagi tubuh agar bisa semakin sehat dan bugar, misalnya tempat spa sebagai tempat merawat tubuh dengan menggunakan aneka bahan alami dan rempah khas. Tempat yang menjadi favorit untuk spa adalah di Bali dan Yogyakarta. Terakhir wisata meeting, incentive, convention, exhibition (MICE), yaitu menawarkan berbagai tempat untuk mengadakan konferensi internasional sekaligus menawarkan potensi wisata yang ada di daerah tersebut. Misalnya, konferensi Suku Hainan Sedunia yang di selenggarakan di Medan 2013, selain mengadakan konferesi, mereka juga berjalan-jalan mengenal potensi pariwisata kota Medan.

\section{Bisnis}

Dari sudut pandang investor, pelayanan jasa di Indonesia masih rendah mutunya. Menurut mereka sistem pelayanan servis dari Indonesia tidak memperhatikan mutu pelayanannya. Hal ini dialami biasanya saat mempekerjakan masayarakat lokal baik untuk sektor pekerja di perusahaan, maupun jasa urusan lainnya seperti jasa pembantu dan supir. Banyaknya masalah pada sektor jasa tidak hanya karena mutu sumber daya manusianya saja, tetapi juga karena budaya bekerja masyarakat Indonesia. Salah satu Informan merasa menurutnya sangat berbeda budaya bekerja di Indonesia dengan budaya bekerja di negara asalnya, Jepang.

“...sistem pelayanan servis dari Indonesia tidak memeperhatikan untuk mutunya supir, mutunya pembantu, jadi ya banyak masalah, hampir setiap bulan mereka tukar-tukar begitu... Masalahnya, kalau perusahaan Jepang, biasa kalau perusahaan besar, sekali kita kerja seumur hidup, karena budayanya begitu, tapi orang Indonesia. setahun ganti, setahun ganti hampir setiap bulan mereka tukar-tukar." (Wawancara informan)

Selain hal tersebut, masalah komunikasi juga menjadi halangan yang harus diperbaiki.
Seringkali terdapat kesulitan yang dialami Investor terutama masalah berkomunikasi bahkan dengan menggunakan bahasa Inggris yang dasar sekalipun. Permasalahan kualitas sumber daya manusia pada sektor jasa tersebut juga diperparah dengan seringnya mereka meminta kenaikan gaji yang harus dituruti karena naiknya keperluan hidup sehari-hari. Walau terkadang dapat dimaklumi, masalah kenaikan gaji tersebut dinilai tidak efektif dan malah merugikan pihak Investor tersebut. Hal tersebut dikarenakan kenaikan gaji pokok tidak selalu diiringi dengan peningkatan mutu sektor jasa. Investor seringkali melihat bahwa seharusnya sudah menjadi tanggung jawab pemerintah dalam menaikan mutu sumber daya manusia. Namun yang selama ini terjadi justru seakan-akan pemerintah tidak mau tahu mengenai mutu pekerja, tidak seperti seharusnya.

"ya mungkin karena nggak bisa bahasa maupun sekarang karena gaji pokok mulai tinggi. Akan tetapi tidak diiringi dengan kualitas yang ikut meningkat... ya, kasih naik gaji okay, tapi mutu juga harus naik, ini pemerintah harus ubah, pemerintah ya sekarang saja okay okay okay, ini nggak bisa, pejabat pemerintah hanya cuci tangan saja..." (Wawancara informan)

Selain itu, iklim birokrasi dalam pengurusan perizinan juga menjadi kendala dalam perkembangan investasi. Salah satu pengalaman yang diceritakan oleh informan adalah saat ia berhadapan dengan bea cukai,

"sudah mulai berubah, tapi, kalau dulu zaman saya, saya akan keliling di kantor bea cukai sampai 41 meja, kalau sekarang sudah lumayan, tapi masih ada... kurang efisien". (wawancara Informan)

Menurutnya, walaupun kinerja pemerintah Indonesia belum mencapai tahap maksimal dan masih terdapat kekurangan, namun mereka sudah mulai menuju tahap yang lebih baik. Kurang lebih 40 tahun berada di Indonesia, Informan melihat mulai ada perubahan yang signifikan dalam proses pelayanan pemerintah terhadap investor seperti dirinya.

Kemudian hal lain yang juga masih harus diperbaiki oleh pemerintahan Indonesia adalah masalah sarana dan prasarana. Macet, adalah satu hal yang menurutnya menjadi masalah terbesar di Indonesia, terutama Ibukota Jakarta, masalah yang belum dapat diatasi oleh pemerintah. Hal tersebut juga terkait dengan permasalahan terlalu padatnya Ibukota namun tidak diimbangi dengan sarana 
dan prasarana yang memadai. Salah satu informan berpendapat,

"Jadi kita nggak puas, segala sarana prasarana beres, ini di dunia kalau ibukota Sarana prasarana harus menunjang....Ya sekarang ini coba yang tinggal 10 juta orang saja, dengan sendirinya akan macet, itu aja nggak bisa beres." (Wawancara Informan)

Menurut informan yang berasal dari kalangan bisnis, Indonesia memiliki keunikan tersendiri dibandingkan dengan Negara lainnya yaitu filsafat Negara dan rasa kemanusiaan. Keunikan Pancasila sebenarnya dapat menjadi brand Indonesia di mata dunia. Seperti pendapat salah satu informan di atas, seandainya pemerintahan dapat mengejawantahkan nilai-nilai luhur dalam filsafat negara, ia yakin hal tersebut dapat menjadi brand Indonesia di mata dunia.

"Saya percaya kalau filsafatnya unggul, manusia jadi sohor, kalau manusia jadi sohor, tanah akan jadi subur. Jadi, asal filsafat negara itu baik, itu tanah, tanah air akan subur, itu. Ini adalah satu rumusan mutlak. Indonesia dulunya menggambarkan dengan pancasila, apakah itu dari asas benar atau apa, yang pentingnya orang Indonesia bisa melambangkan dengan asas negara pancasila sebagai filsafat negara atau tidak, bisa menyatu atau tidak, itu kalau itu dijalankan, kalau pancasila unggul, dengan sendirinya meskipun ada berbagai gejolak, tapi tanah air akan subur, tapi sayang, karena banyak oknum-oknum yang dipakai, atau dimanfaatkan atau menyalahgunakan atau macam-macam..." (Wawancara Informan)

Masalahnya, meski Indonesia memiliki filsafat negara yang unik dan dapat menjadi brand Indonesia di mata dunia, namun ternyata pemerintah sendiri belum menyadarinya bahkan beberapa oknum justru merusak citra tersebut.

Salah satu yang membuatnya iri adalah budaya masyarakat Indonesia terhadap orang tua. Menurutnya sangat berbeda dengan apa yang ia rasakan di negara asalnya Jepang, masyarakat Indonesia tidak merasa terbebani untuk mengurus orang tua yang berusia lanjut, sedangkan di Jepang, mengasuh orang tua yang telah berusia lanjut bisa menjadi beban. Dalam hal ini ia melihat bahwa selain karena budaya Indonesia sendiri, hal tersebut bisa jadi tidak terlepas dari besarnya peranan dari kehidupan beragama orang Indonesia.

"karena dasarnya orang Indonesia dibesarkan dengan keluarga besar. jadi penuh dengan peri kemanusiaan, jadi, kalau untuk mengurus orang tua itu bukan menjadi beban, dengan sendirinya. Tapi kalau orang Jepang kalau mengurus orang tua, usia lanjut, itu akan jadi beban. karena mungkin, selain dari, sebagai, iklim, budaya dari Indonesia sendiri atau mungkin karena agama" (Wawancara informan)

Demikian paparan seorang informan yang berasal dari Jepang mengenai keunikan budaya Indonesia yang menurutnya tidak ia temui di negara asalnya.

\section{Masyarakat Sipil}

Dimensi nation brand Indonesia yang menjadi perhatian salah satu ekspatriat di Indonesia adalah produk. Daya tahan produk adalah salah satu hal yang masih disesali para pembeli. Seorang informan bercerita pengalamannya memakai produk Indonesia, dan mendapati kualitasnya cukup buruk, karena ia pernah membeli sepatu yang hanya tahan selama enam bulan saja. Selain itu ada sedikit masalah terkait pelayanan jasa, yang harus diperbaiki. Seorang informan mengaku bahwa sebenarnya pelayanan yang ia dapatkan di Indonesia baik, namun sering tidak efisien. Tetapi hal tersebut diakuinya masih lebih baik dibanding di beberapa negara lainnya.

Pelayanannya baik dan sangat membantu tetapi tidak efisien, contohnya saat saya datang ke mall di Indonesia saya akan diserbu oleh 10 orang pelayan. Sementara di UK (Inggris, pen), 10 orang pelanggan hanya dilayani oleh satu pelayan. Berbeda dengan Cina, yang pelayanannya tidak baik dan tidak membantu. (Wawancara Informan)

Produk lain yang juga menjadi andalan Indonesia adalah makanan. Pengurus Dewan Kerajinan Nasional Daerah (Dekranasda), Veronica Tan, berencana setelah batik fokus perluasan produk khas indonesia adalah makanan dan minuman. Menurut dia, keanekaragaman resep dan produk kuliner merupakan salah satu kekayaan tradisional nusantara. Seorang informan yang berasal dari luar negeri juga mengakui bahwa makanan khas Indonesia sebagai salah satu daya tarik dari Indonesia. Ia mengaku menyukai makanan khas Indonesia seperti tempe, sambal, ikan bakar, dan rendang. Namun informan lain yang berasal dari luar negeri ada pula yang tidak menyukai makanan khas indonesia, khusunya yang memakai sambal, yang menurutnya justru dapat merusak cita rasa 
original masakan tersebut. Hampir semua masakan yang menggunakan sambal, menurutnya yang terasa hanya pedas dan kurang cocok bagi lidah wisatawan semacam dirinya.

Dari sisi pemerintahan dinilai cukup baik, karena diakui oleh beberapa informan bahwa Indonesia dalam perjalanan menuju demokrasi. Salah satu informan menganggap Indonesia lebih hebat budaya politiknya, lebih baik dari Singapura dan Vietnam. Namun beberapa hal masih menjadi hambatan untuk bisa mencapai pemerintahan yang diidamkan. Misalnya, terlalu banyak korupsi padahal orangorangnya mengetahui demokrasi, terlalu banyak birokrasi dan koordinasi antarbagian di dalam pemerintahan dilakukan sendiri-sendiri, serta banyaknya aturan yang kadang tidak selaras antar departemen. Hal tersebut dirasakan oleh salah satu informan yang berasal dari LSM (Lembaga Swadaya Masyarakat) yang akhirnya menghambat kinerja LSM tersebut untuk bergerak meskipun terkait untuk hal yang bersifat positif sekalipun, dalam hal ini untuk membangun sekolah.

Banyak aturan, yang kadang tidak selaras antar departemen. kami menemukan kegelisahan dari teman-teman PU karena di Permendiknas no. 24 tahun 2007 itudiduga menurutmereka, tidakselaras, tidak sinkron dengan peraturan pembangunan Negara. tentang pembangunan bangunan Negara, jadi semua bangunan yang dibangun dengan $A P B N$ dan $A P B D$ harus melibatkan PU. (Wawancara informan)

Banyaknya korupsi dan segala macamnya itulah yang diyakini para informan dapat menghambat perjalanan Indonesia menuju demokrasi yang ideal. Perlu adanya sinkronisasi kebijakan, peningkatan partisipasi publik dan kelembagaan yang baik adalah masukan dari para masyarakat sipil demi mencapai pemerintahan yang ideal.

Informan yang berasal dari luar negeri menilai positif masyarakat Indonesia terutama sifat ramahtamahnya yang mereka yakini sudah menjadi budaya khas Indonesia. Menurut mereka, nilai lebih Indonesia ada pada orang-orangnya yang ramah, suka menyapa, dan orang Indonesia cenderung terbuka. Masyarakat Indonesia juga dinilai baik, bersahabat, kuat dan kalem. Banyak hal yang menarik perhatian yang dirasakan sangat berbeda dengan di negara asal mereka, dan menurut mereka masyarakat Indonesia justru lebih baik dalam kehidupan sosialnya.

Informan yang berasal dari luar negeri berpendapat bahwa budaya masyarakat indonesia seperti yang dialaminya selama berinteraksi dengan mereka juga dipengaruhi oleh iklim dan geografis. Ia berpendapat bahwa iklim yang sangat berbeda antara negaranya dan Indonesia berpengaruh pada banyak aspek kehidupan masyarakat. Salah satu yang dilihat adalah bagaimana orang Indonesia memiliki sifat terbuka (ekstrovert) dan tidak memiliki sifat penuh dengan kecemasan (anxiety disorder).

Terdapat beberapa hal yang tidak disukai para orang asing pada masyarakat Indonesia. Hal yang tidak disukai pada masyarakat Indonesia adalah mereka cenderung lalai dan tidak disiplin. Masyarakat Indonesia memiliki kesadaran yang kurang dan kurang disiplin, misalnya pada masalah kebersihan seperti membuang sampah sembarangan. Mereka juga kurang menyukai gaya hidup masyarakat Indonesia yang menyebabkan perbedaan antara orang kaya dan miskin terlalu terlihat.

Para informan yang berasal dari luar negeri merasa betah untuk tinggal dan bekerja di Indonesia. Selain itu mereka juga merasakan pengalaman yang baik di lingkungan tempat tinggalnya. Menurut salah satu informan, tetangga di tempat tinggalnya juga sangat bersahabat, sampai-sampai ia tidak sadar telah membawa kebiasaan dalam keseharian orang-orang Indonesia tersebut saat ia kembali ke negaranya.

"Saya sering ketika berjalan, orang-orang memanggil 'bule mau ke mana?', saya jawab saja 'jalan-jalan'. Sementara di UK, hal tersebut tidak saya jumpai, malah ketika ada yang menyapa, mereka akan mengumpat 'It is not your business!'. Tetangga saya di Kebon Kacang sangat ramah, mereka bahkan meneriaki saya ketika sedang menyebrang jalan 'awas Mister'. Saya pun reflek, ini terbawa sampai di UK, ketika ada yang sembarangan menyeberang jalan, saya berteriak 'awas!'. Hahaha.. Dan saya menikmati itu semua." (wawancara informan)

Hal itu pula yang menjadikan mereka tidak memiliki kekhawatiran untuk tinggal di Indonesia. Bahkan salah satu informan mengaku ia sangat senang tinggal di Indonesia dan ingin tinggal lama di Indonesia dan berharap dapat membawa istri dan anaknya untuk tinggal bersamanya di Indonesia.

\section{KESIMPULAN}

Keberadaan tiga komponen (pemerintah, bisnis dan masyarakat sipil) yang disebut dengan triplehelix dalam membangun nation brand menjadi 
penting dan tidak dipisahkan. Pentingnya triplehelix pada sisi pemerintah dapat diperkuat dengan melakukan kualitas sistem pelayanan terpadu dalam mempercepat proses perizinan calon investor. Oleh karena itu reformasi birokrasi atau revolusi mental serta sinkronisasi antar sektor dan antar regulasi menjadi cara-cara yang diperlukan untuk meningkatkan kemampuan pemerintah.

Sedangkan pada sisi bisnis, penguatan diperlukan ada dua hal. Pertama, perlunya penguatan pada kualitas sumber daya manusia dan budaya mental bekerja.Salah satunya penguatan dengan memberikan pelatihan bahasa Inggris. Sedangkan yang kedua adalah penguatan infrastruktur, fasilitas dan pelayanan dalam menunjang produktivitas industri. Keadaan ini dapat diatasi dengan memberikan filosofis kenegaraan seperti Pancasila dan nilai-nilai luhurnya. Sementara, pada sisi masyarakat sipil, produk buatan Indonesia memerlukan peningkatan pada kemasan dan daya tahannya. Dengan adanya andalan produk Indonesia dalam bidang fashion batik, resep dan produk kuliner, maka sifat ramahtamah masyarakat Indonesia menjadi lebih lengkap dan lebih baik dalam memperkuat nation brand Indonesia.

Penelitian triplehelix nation brand Indonesia masih memerlukan kajian lebih dalam dan detail. Kajian mendalam diperlukan untuk menyusun regulasi dan kebijakan yang mendukung nation brand, mengekstraksi nilai-nilai kultural filosofis yang berasosiasi dengan Indonesia sebagai bangsa ramah tamah dan bertoleransi, serta menemukan produk-produk seperti fashion dan kuliner tradisional yang menjadi ciri khas nation brand Indonesia. Oleh karena itu disarankan pada penelitian selanjutnya untuk menggali lebih dalam pada ketiga kondisi yang mampu memperkuat dan mengimplementasikan kekuatan bangsa sebagai nation brand.

\section{DAFTAR PUSTAKA}

Adiningsih, S., Rahutami, A. I, Anwar, R.P., Wijaya, R.A.S., \& Wardani, E.M. (2008). Satu Dekade PascaKrisis Indonesia: Badai Pasti Berlalu, Yogyakarta: Penerbit Kanisius.

Aminuddin. (2011) Hidup Matrialistis Telah Membawa Kita Kepada Krisis Kepemipinan Dan Krisis Multidimensional, retrieved from citizen news.suaramerdeka.com, http://citizennews. suaramerdeka.com/?option $=$ com_content $\&$ task=view\&id=1478.
Antara. (2011) Mendag: Indonesia Perlu Lakukan "Nation Branding", retrieved on Februari 21, 2016 from http://www.antaranews.com/berita/269434/ mendag-indonesia-perlu-lakukan-nationbranding.

Balipost.co.id. (2003) Turun Drastis, Sumbangan Pariwisata terhadap PRDB Bali, Retrieved on August 11, 2003 from http://www.balipost.co.id/ balipostcetak/2003/7/31/par2.htm

Bambang. (2007, June 4). Indonesia Siapkan "Branding" Nasional. Dipetik January 16, 2013, dari Antara News.com: http://www.antaranews.com/ view/?i=1180954610\&c $=$ NAS\&s $=$

Bloom Consulting Enterprenuers. (2011). Country Brand Ranking. Madrid.

Brand Finance. (2011). The Brand Finance ${ }^{\circledR}$ Nation Brands 100. London, United Kingdom.

Bryman, A. (2008). Social Research Methods. New York: Oxford University Press.

Burhani, R. (2009, June 25). Indonesia Tempati Urutan ke-43 Nation Brand Index. Dipetik Januari 16, 2013, dari Antara News.com: http://www.antaranews. $\mathrm{com} / \mathrm{view} / ? \mathrm{i}=1245943534 \& \mathrm{c}=\mathrm{EKB} \& \mathrm{~s}=\mathrm{BIS}$

Chalk, P (2013) Encyclopedia of Terrorism, California: ABC-CLIO LLC.

Diakses dari http://file.upi.edu/Direktori/FPTK/ JUR._PEND._KESEJAHTERAAN_KELUARGA/ SUNARSIH/KOMUNIK__KELUARGA.pdf, p. 4

Dinnie, Keith; T.C. Melewar, Kai-Uwe Seidenfuss and Ghazali Musa. (2010). Nation Branding and Integrated Marketing Communications: an ASEAN perspective.

Dong-Hun, Lee. (2010). Nation Branding Korea. April.

Febrina, N., \& Irwansyah. (2014). Top of Mind merek Bangsa Indonesia. Masa Depan Komunikasi, Masa Depan Indonesia: Geopolitik dan Geostrategi, I(7), 127-144.

Future Brand. (2012). Country Brand Index 2012-13. London, New York, Shanghai.

GfK Roper Public Affairs \& Corporate Communications. (2010, October). The Anholt-GfK Roper Nation Brands IndexSM 2010 Report. New York, New York, United States of America.

Gordon, Theodore J. (1994). The Milenium Project - The Delphi Method. Diakses dari: www.gerenciamento. ufba.br/Downloads/delphi\%20(1).pdf tanggal 13 Maret 2013.

Hapsari, Tia. (2009). Rektor UI: Bom Tak Pengaruhi Jumlah Mahasiswa Asing. http://www.tempo.co/ $\mathrm{read} /$ news/2009/07/27/079189243/Rektor-UI-Bom- 
Tak-Pengaruhi-Jumlah-Mahasiswa-Asing.

Hasan, R. (2007, September 5). Pemimpin Tak Konsisten, Country Branding Indonesia Lemah. Dipetik January 16, 2013, dari Tempo.co: http:// www.tempo.co/read/news/2007/09/05/056106930/ Pemimpin-Tak-Konsisten-Country-BrandingIndonesia-Lemah

Hasan, Rofiqi. (2007). Indonesia's Country Branding Weak due to Inconsistent Leaders. http:// www.tempo.co.id/hg/nasional/2007/09/05/ brk,20070905-106960,uk.html, diakses 24 April 2013.

Hidayat, H. (2008). Politik Lingkungan: Pengelolaan Hutan Masa Orde Baru dan Reformasi, Jakarta: Yayasan Obor Indonesia.

Indonesiamedia.com (2013) 26 Desember 2004: Gempa Bumi dan Tsunami di Aceh, retrieved on August 11, 2013, from http://www.indonesiamedia. com/2012/12/26/26-desember-2004-bencanagempa-bumi-dan-tsunami-di-aceh

Irwansyah. (2013). Menginisiasi Nation Branding Indonesia Menuju Daya Saing Bangsa. Jurnal Ilmu Komunikasi, 11(1), 80-91.

Istman, MP. "Ekonomi Indonesia Tumbuh, Kelas Menengah Bahagia". http://www.tempo.co/read/ news/2012/08/13/090423273/Ekonomi-IndonesiaTumbuh-Kelas-Menengah-Bahagia. diakses pada 5 Februari 2012.

Kasali, R. (2012, September 13). Merosotnya Daya Saing. Dipetik January 16, 2013, dari Harian Seputar Indonesia: http://www.seputar-indonesia.com/ edisicetak/content/view/526191/38/

Liliweri, Alo. (1997). Komunikasi Antarpribadi. Bandung : PT.Citra Aditya Bakti.

Maheshwari, V., Vandewalle, I., \& Bamber, a. D. (2011). Place branding's rolein sustainable development. Journal of Place Management and Development, 198.

Muftisany, Hafidz . (2012). Minat Mahasiswa Asing Kuliah di Indonesia Tinggi. http://www.republika. co.id/berita/nasional/umum/12/06/05/m54k0sminat-mahasiswa-asing-kuliah-di-indonesia-tinggi
Nadjib, Supadiyanto Espede Ainun. (2012). Review II: Teori-Teori Komunikator, para.10-11. Diakses dari http://media.kompasiana.com/ new-media/2012/09/18/review-ii-teori-teorikomunikator-487742.html

Oentoro, J. (2010). Indonesia Satu, Indonesia Beda, Indonesia Bisa, Jakarta: PT. Gramedia Pustaka Utama.

Outhavong, Sounthaly. (2007). Branding "National Brand". Austin: The University of Texas.

Papadopoulos, Nicolas. (2004). Papers Place branding: Evolution, meaning and implications. Diakses dari http://193.146.160.29/gtb/sod/usu/\$UBUG/ repositorio/10300753_Papadopoulos.pdf

Popy, R. (2007). Branding the nation: Indonesia as a Brand. Dipetik January 16, 2013, dari Ideas.Repec. org: http://ideas.repec.org/p/unp/wpaman/200706. html

Punch, K. F. (2003). Survey Research: The Basics. London: Sage Publications Ltd.

Suleman, Z, \& Junaedhie, K. (2010). Demokrasi untuk Indonesia: Pemikiran Bung Hatta, Jakarta: Penerbit Buku Kompas.

Sun, Qin. (2009). Doctoral Dissertasion. An Analitycal Model of The Determinants and Outcomes of Nation Branding (Texas : University of North Texas).

Surya, T. A. (2007). Strategy Nation Branding Campaign Indonesia Ultimate in Diversity. Dipetik January 16, 2013, dari Fikom Library and Knowledge Center: http://lib.fikom.unpad.ac.id/digilib/gdl.php ?mod=browse\&op=read\&id=jbptunpadfikom-gdltitaayudit-621.

Ulfah, M. (2012). Analisis Potensi Ekspor Produk Makanan dan Minuman Olahan Indonesia di Pasar Non- Tradisional Asia . Bogor: Institut Pertanian Bogor.

Warta Ekonomi (1998). Mingguan Berita Ekonomi dan Bisnis, Volume 10, Issues 28-36, Jakarta, Obor Sarana Utama. 